\title{
PEMBATALAN PERJANJIAN JUAL BELI HAK ATAS TANAH AKIBAT ADANYA UNSUR KHILAF
}

\author{
Fajaruddin
}

\author{
Fakultas Hukum Universitas Muhammadiyah Sumatera Utara \\ E-mail: fajaruddin_umsu@yahoo.co.id
}

\begin{abstract}
The occurrence of wanprestasi in an engagement as a source of sale and purchase agreement that always begins with contractual relationships (characteristics of default is always preceded by a contractual relationship) can be caused by some elements of which one of the elements is err. As a result of the law, the land purchase agreement which is made contains elements of khilaf reflected in Article 1321 and 1449 Civil Code. Article 1321 Civil Code: Affirms: "There is no legitimate agreement if the agreement is given by mistake, or obtained by coercion or fraud", and Article 1449 of the Civil Code states: "A contract made by force, an oversight or a fraud, publishes a demand to annul it".
\end{abstract}

\section{Kata Kunci: Hak Atas Tanah, Jual Beli, Perjanjian}

\section{A. Latar Belakang}

Tanah merupakan kebutuhan pokok manusia, yang dalam kehidupan manusia mempunyai arti sangat penting, karena sebagian besar dari kehidupan manusia salah satunya bergantung pada keberadaan dan kepemilikan hak atas tanah. Tidak saja sebagai tempat bermukim, tempat untuk bertani, tetapi tanah juga dapat juga dipakai sebagai jaminan untuk mendapatkan pinjaman perbankan untuk keperluan jual beli dan sewa menyewa (Angger Sigit Pramukti dan Erdha Widayanto, 2015:1).

Dalam kaitan perolehan/penguasaan tanah bagi kepentingan dunia usaha dan kepentingan masyarakat, selain melalui penyusunan tata ruang juga pada proses pemberian izin lokasi. Pemberian izin lokasi melalui proses koordinasi antar instansi terkait disertai peninjauan lokasi guna meneliti berbagai aspek termasuk kondisi eksisting, agar benar-benar sesuai dengan rencana tata ruang, ketersediaan dan kemampuan tanah, prospek pengembangan dan sinergitas dengan kepentingan masyarakat (Mohammad Machfudh Zarqoni, 2015: 2). 
Meningkatnya kebutuhan ekonomis terhadap hak atas tanah yang berbanding terbalik dengan ketersediaan jumlah bidang tanah (cenderung bersifat statis) menjadi salah satu faktor pemicu lonjakan angka sengketa, konflik dan perkara pertanahan yang terjadi di Indonesia dewasa ini (Rahmat Ramadhani, 2012: 4). Salah satu penyebab munculnya permasalahan hukum dalam perolehan dan perlaihan hak atas tanah adalah yang berasal dari jual beli.

Berbicara tentang jual beli, tentunya bertalian erat dengan syarat sahnya suatu perjanjian. Dalam sebuah perjanjian maka pihak-pihak yang mengangkat janji memiliki kewajiban yang sama dalam mewujudkan prestasi yang ditelah diperjanjikan. Oleh karena itu, para pihak (baik pihak penjual maupun pihak pembeli) memiliki kewajiban untuk memenuhi prestasi tersebut, dan jika salah satu para pihak yang mengangkat janji tidak melaksanakan kewajibannya untuk memenuhi prestasi sebagaimana yang telah diperjanjikan dan bukan disebabkan karena keadaan memaksa (prosmejeur), maka keadaan demikian dikenal dengan sebutan wanprestasi (ingkar janji).

Ingkar janji (wanprestasi) dalam Kitab Undang-undang Hukum Perdata (selanjutnya disingkat KUH Perdata) diatur pada Pasal 1234, yang menyatakan bahwa; "tiap-tiap perikatan adalah untuk memberikan sesuatu, untuk berbuat sesuatu, atau untuk tidak berbuat sesuatu”, kemudian Pasal 1235 KUH Perdata menyebutkan bahwa: "dalam tiap-tiap perikatan untuk memberikan sesuatu adalah termasuk kewajiban si berutang untuk menyerahkan kebendaan yang bersangkutan dan untuk merawatnya sebagai seorang bapak rumah yang baik, sampai pada saat penyerahan".

Dalam konteks perjanjian jual beli hak atas tanah, pada dasarnya ingkar janji merupakan hal dominan sebagai pemicu batalnya suatu penjanjian, tetapi harus dikaji pula beberapa alasan terjadinya ingkar janji tersebut sebagai unsur penyebab batalnya suatu perjanjian jual beli hak atas tanah. Ada beberapa penyebab ingkar janji yang berimbas pada batalnya suatu perjanjian, yaitu salah satunya adalah unsur khilaf, dan oleh sebab itu penulis tertarik untuk mengkaji lebih dalam hal yang terkait dengan batalnya perjanjian jual beli hak atas tanah akibat adanya (terpenuhinya) unsur khilaf. 


\section{B. Metode Penelitian}

Penelitian hukum dilakukan untuk mencari pemecahan atas isu hukum yang timbul, yaitu memberikan preskripsi mengenai apa yang seyogyanya atas isu yang diajukan (Dyah Ochtorina Susanti dan A'an Efendi, 2014: 1). Jenis penelitian ini adalah penelitian hukum normatif (yuridis normatif), dengan pendekatan perundang-undangan dan pendekatan terhadap asas hukum. Sifat penelitian yang digunakan adalah deskriptif analitis, yaitu penelitian yang hanya semata-mata melukiskan keadaan objek atau peristiwanya tanpa suatu maksud mengambil kesimpulan-kesimpulan yang berlaku secara umum.

Penelitian hukum normatif merupakan penelitian yang mengkaji dokumen dari berbagai data sekunder seperti peraturan perundang-undangan, keputusan pengadilan, dan pendapat para ahli hukum, sehingga sumber data yang digunakan dalam penelitian ini adalah data yang diperoleh metode studi dokumen, yang terdiri dari; bahan hukum primer yaitu bahan-bahan hukum yang mengikat, yakni peraturan perundang-undangan yang terkait, bahan hukum sekunder berupa buku dan jurnal atau artikel lain yang dipublikasikan, serta bahan hukum tersier yang diakses dari internet.

Analisis data yang sesuai dengan penelitian deskriptif adalah dengan menggunakan analisis kualitatif, yaitu analisis data yang mengungkapkan dan mengambil kebenaran yang diperoleh dari kepustakaan yaitu dengan menggabungkan antara peraturan dan buku yang ada hubungannya dengan masalah penelitian, atau menurut Tengku Erwinsyahbana (2017: 188-189), lebih tepatnya disebut analisis yuridis kualitatif, karena yang dianalisis adalah informasi yang didapat dari peraturan perundang-undang, serta tulisan-tulisan ilmiah dalam bidang hukum (yuridis).

\section{Hasil Penelitian dan Analisis}

\section{Syarat sah dan jenis perjanjian}

Pasal 1313 KUH Perdata menguraikan bahwa perjanjian adalah suatu peristiwa di mana seorang berjanji kepada seorang lain atau di mana dua orang itu saling berjanji untuk melaksanakan sesuatu hal. Dari uraian tersebut terlihat 
bahwa perjanjian menimbulkan suatu hubungan hukum antara dua orang atau lebih yang lazim dinamakan perikatan. Dari sisi substansinya, perjanjian berisikan suatu rangkaian perkataan yang mengandung janji-janji atau kesanggupan baik secara lisan maupun tertulis.

Istilah perjanjian erat kaitannya dengan kontrak. Kontrak berasal dari Bahasa Inggris yaitu contract (kontrak), sedangkan dalam Bahasa Belanda disebut dengan overeenkomst (perjanjian). Hukum kontrak mengenal lima (5) asas penting, yaitu asas kebebasan berkontrak, asas konsensualisme, asas pacta sun servanda (asas kepastian hukum), asas ikhtikad baik, dan asas kepribadian (Salim H.S., 2014: 9).

Suatu hubungan hukum yang tercipta antara orang-orang yang membuatnya yang disebut perikatan kerap tertuang dalam bentuk tulisan yang disebut dengan kontrak, dan Rai Widjaya (2007: 21), mengatakan bahwa dalam suatu perikatan (verbintenis) terkandung hal-hal sebagai berikut:

a. adanya hubungan hukum;

b. biasanya mengenai kekayaan atau harta benda;

c. antara dua orang pihak/lebih;

d. memberikan hak kepada yang satu, yaitu kreditur;

e. meletakkan kewajiban pada pihak yang lain, yaitu debitur; dan

f. adanya prestasi.

Syarat sahnya suatu perjanjian tegas tercantum pada Pasal $1320 \mathrm{KUH}$ Perdata yang menentukan, bahwa sepakat mereka yang mengikatkan dirinya, cakap untuk membuat suatu perjanjian, mengenai suatu hal tertentu dan suatu sebab yang halal. Perjanjian baru mengikat dan mempunyai akibat hukum apabila perjanjian tersebut sudah memenuhi syarat-syarat yang sudah ditentukan dalam Pasal 1320 KUH Perdata (Ahmadi Miru, 2014:13), yaitu:

a. Sepakat mereka yang mengikat dirinya

Syarat pertama merupakan awal dari terbentuknya perjanjian, yaitu adanya kesepakatan antara para pihak tentang isi perjanjian yang akan mereka laksanakan. Oleh karena itu, timbulnya kata sepakat tidak boleh disebabkan oleh tiga hal, yaitu adanya unsur paksaan, penipuan, dan kekeliruan. Apabila 
perjanjian tersebut dibuat berdasarkan adanya paksaan dari salah satu pihak, maka perjanjian tersebut dapat dibatalkan.

b. Cakap membuat suatu perjanjian;

Saat penyusunan kontrak, para pihak khususnya manusia secara hukum telah dewasa atau cakap berbuat atau belum dewasa tetapi ada walinya. Di dalam KUH Perdata yang disebut pihak yang tidak cakap untuk membuat suatu perjanjian adalah orang-orang yang belum dewasa dan mereka yang berada di bawah pengampuan.

c. Mengenai hal tertentu;

Secara yuridis suatu perjanjian harus mengenal hal tertentu yang telah disetujui. Suatu hal tertentu di sini adalah obyek perjanjian dan isi perjanjian. Setiap perjanjian harus memiliki obyek tertentu yang jelas dan tegas, sehingga obyek diperjanjikan harus jelas (tidak mengira-ngira).

d. Suatu sebab yang halal.

Setiap perjanjian yang dibuat para pihak tidak boleh bertentangan dengan undang-undang, ketertiban umum dan kesusilaan.

Dalam akta perjanjian syarat pertama dan kedua disebut syarat subyektif, yaitu syarat mengenai orang-orang atau subyek hukum yang mengadakan perjanjian. Apabila kedua syarat ini dilanggar, maka perjanjian tersebut dapat diminta pembatalan. Syarat ketiga dan keempat merupakan syarat obyektif, yaitu mengenai obyek perjanjian dan isi perjanjian, dan jika syarat tersebut dilanggar, maka perjanjian tersebut batal demi hukum.

Syarat-syarat subyektif adalah mengenai orang-orang atau subyek yang mengadakan perjanjian, apabila syarat-syarat subyektif tidak terpenuhi maka perjanjian dapat dibatalkan oleh hakim atas permintaan pihak yang tidak cakap atau memberikan kesepakatan secara tidak bebas, selama perjanjian itu tidak dibatalkan maka perjanjian tersebut tetap mengikat. Dalam Pasal 1330 KUH Perdata disebut sebagai orang-orang yang tidak cakap untuk membuat suatu perjanjian, yaitu: (a) orang-orang yang belum dewasa; dan (b) mereka yang ditaruh di bawah pengampuan. Terhadap syarat-syarat obyektif yang tidak dipenuhi, maka perjanjiannya batal demi hukum, artinya dari semula tidak pernah 
dilahirkan suatu perjanjian dan tidak pernah ada perikatan, maka tiada dasar untuk saling menuntut dimuka umum hakim (pengadilan).

Perjanjian merupakan suatu hubungan hukum yang berarti bahwa yang bersangkutan haknya dijamin dan dilindungi oleh hukum atau undang-undang, sehingga apabila haknya tidak dipenuhi secara sukarela, dia berhak menuntut melalui pengadilan supaya orang yang bersangkutan dipaksa untuk memenuhi atau menegakkan haknya, menurut Wawan Muhwan Hariri (2011: 1-48), dijelaskan beberapa jenis perjanjian, yaitu:

a. Perjanjian timbal balik dan perjanjian sepihak

Merupakan perjanjian yang memberikan hak dan kewajiban kepada kedua belah pihak, misalnya perjanjian jual beli, sewa menyewa, tukar menukar. Perjanjian sepihak merupakan perjanjian yang memberikan kewajiban kepada satu pihak dan hak kepada pihak lainnya, misalnya perjanjian hibah, dan hadiah. Perbedaan ini mempunyai arti penting dalam praktik terutama dalam soal pemutusan perjanjian menurut Pasal 1266 KUH Perdata yang menyatakan bahwa syarat batal dianggap selalu dicantumkan dalam persetujuanpersetujuan yang bertimbal balik, apabila salah satu pihak tidak memenuhi kewajibannya. Menurut pasal ini salah satu syarat adanya pemutusan perjanjian itu apabila perjanjian itu bersifat timbal balik.

b. Perjanjian percuma dan perjanjian dengan alas hak yang membebani Perjanjian percuma merupakan perjanjian yang memberikan keuntungan pada satu pihak saja, misalnya perjanjian pinjam pakai, dan perjanjian hibah, sedangkan perjanjian dengan alas hak yang membebani adalah perjanjian dalam mana terhadap prestasi dari pihak yang satu selalu dapat kontra prestasi dari pihak yang lainnya, dan antara kedua prestasi itu ada hubungannya menurut hukum. Pembedaan ini mempunyai arti penting dalam soal warisan berdasarkan undang-undang dan mengenai perbuatan yang merugikan para kreditur (Pasal 1341 KUH Perdata).

c. Perjanjian bernama dan tidak bernama

Perjanjian bernama adalah perjanjian yang mempunyai nama sendiri, yang dikelompokkan sebagai perjanjian-perjanjian khusus, karena jumlahnya 
terbatas, misalnya jual beli, sewa menyewa. Perjanjian tidak bernama adalah perjanjian yang tidak mempunyai nama tertentu dan jumlahnya tidak terbatas.

d. Perjanjian kebendaan dan perjanjian obligatoir

Perjanjian kebendaan (zakelijke, overeenkomst, delivery contract) adalah perjanjian untuk memindahkan hak milik dalam perjanjian jual beli. Perjanjian kebendaan ini sebagai pelaksanaan perjanjian obligator. Perjanjian obligator adalah perjanjian yang menimbulkan perikatan, artinya sejak terjadinya perjanjian timbul hak dan kewajiban pihak-pihak pembedaan ini adalah untuk mengetahui apakah dalam perjanjian itu ada penyerahan (levering) sebagai realisasi perjanjian, dan penyerahan itu sah menurut hukum atau tidak.

e. Perjanjian konsensual dan perjanjian real

Perjanjian konsensual adalah perjanjian yang timbul karena ada persetujuan kehendak antara pihak-pihak, sedangkan perjanjian real adalah perjanjian yang selain ada persetujuan kehendak juga ada penyerahan atas barangnya, misalnya jual beli barang bergerak, perjanjian penitipan, pinjam pakai (Pasal 1694, Pasal 1740, dan Pasal 1754 KUH Perdata). Dalam hukum ada perjanjian real justru yang lebih menonjol sesuai dengan sifat hukum adat bahwa setiap perbuatan hukum yang objeknya benda tertentu, seketika terjadi persetujuan kehendak serentak ketika itu juga terjadi perpindahan hak. Hal ini disebut "kontan/tunai".

\section{Perolehan hak atas tanah berdasarkan perjanjian jual beli}

Istilah perjanjian jual beli berasal dari terjemahan dari contract of sale. Secara materil perjanjian jual beli terhadap hak atas tanah diatur dalam Pasal 1457 KUH Perdata yang menentukan bahwa jual beli adalah suatu persetujuan, dengan mana pihak satu mengikatkan dirinya untuk menyerahkan suatu kebendaan, dan pihak lain untuk membayar harga yang dijanjikan. Salim H.S. (2003: 48), menguraikan unsur-unsur yang tercantum dalam definisi di atas, antara lain:

a. adanya subyek hukum, yaitu penjual dan pembeli;

b. adanya kesepakatan antara penjual dan pembeli tentang barang dan harga; serta

c. adanya hak dan kewajiban yang timbul antara pihak penjual dan pembeli. 
Terjadinya kontrak jual beli antara pihak penjual dan pembeli adalah pada saat terjadinya persesuaian kehendak dan pernyataan antara mereka tentang barang dan harga, meskipun barang itu belum diserahkan maupun harganya belum dibayar lunas (Salim H.S., 2003: 48). Perjanjian yang dilakukan oleh para pihak merupakan juga hukum bagi hubungan konkrit yang bersangkutan. Pasal 1338 KUH Perdata yang menetukan bahwa semua persetujuan yang dibuat sesuai dengan undang-undang berlaku sebagai undang-undang bagi mereka yang membuatnya. Dalam pasal ini, perjanjian tersebut tentu ada batasnya, yaitu khusus di bidang hukum tanah, sepanjang perjanjian yang diadakan itu tidak melanggar undang-undang atau bertentangan ketentuan UUPA (Salim H.S., 2003: 48).

Jual beli hak atas tanah merupakan proses peralihan hak dan jual beli ini didasarkan pada hukum adat, dan harus memenuhi syarat-syarat seperti: terang, tunai dan rill. Terang artinya dilakukan di depan pejabat umum yang berwenang, tunai artinya dibayarkan secara tunai, dan rill artinya jual beli dilakukan secara nyata (Salim H.S., 2003: 48). Apabila harga belum lunas, maka belum dapat dilakukan proses jual beli sebagaimana dimaksud. Secara formil perolehan/ peralihan hak atas tanah berdasarkan perjanjian jual beli diatur dalam Peraturan Pemerintah Nomor 24 Tahun 1997 tentang Pendaftaran Tanah jo. Peraturan Menteri Agraria/Kepala Badan Pertanahan Nasional (PMNA/Ka.BPN) Nomor 3 Tahun 1997 tentang Petunjuk Pelaksanaan Peraturan Pemerintah Nomor 24 Tahun 1997 tentang Pendaftaran Tanah.

Secara formil, hubungan hukum yang terjadi dalam pembuatan penjanjian jual beli hak atas tanah terhadap tanah-tanah yang telah bersertipikat adalah dengan menandatangani Akta Jual Beli (AJB) sebagai akta otentik yang dilakukan di hadapan Pejabat Pembuat Akta Tanah (PPAT). Hal ini didasarkan pada tujuan dilaksanakannya pendaftaran tanah yang salah satunya adalah untuk menjamin kepastian hukum. Dalam rangka mewujudkan kepastian hukum tersebut, maka fungsi pendaftaran tanah tersebut ialah untuk memperoleh alat pembuktian yang kuat tentang sahnya perbuatan hukum mengenai tanah, tetapi untuk perbuatan hukum tertentu, pendaftaran mempunyai fungsi lain, yaitu: untuk memenuhi sahnya perbuatan hukum itu, artinya tanpa dilakukan pendaftaran, perbuatan 
hukum itu tidak terjadi dengan sah menurut hukum (Effendi Perangin-angin, 1996: 96).

Dalam kaitannya dengan pembuatan akta otentik tentang tanah oleh PPAT, Pasal 2 ayat (1) Peraturan Pemerintah Nomor 37 Tahun 1998 disebutkan bahwa PPAT bertugas pokok melaksanakan sebagian kegiatan pendaftaran tanah dengan membuat akta sebagai bukti telah dilakukannya perbuatan hukum tertentu mengenai hak atas tanah atau hak milik atas satuan rumah susun, yang akan dijadikan dasar bagi pendaftaran perubahan data pendaftaran tanah yang diakibatkan oleh perbuatan hukum itu. PPAT berdasarkan Peraturan Pemerintah Nomor 37 Tahun 1998, terdiri dari:

a. PPAT sementara yakni Camat yang oleh karena jabatannya dapat melaksanakan tugas PPAT untuk membuat akta jual beli tanah. Camat di sini diangkat sebagai PPAT untuk daerah terpencil atau daerah-daerah yang belum cukup jumlah PPAT nya.

b. PPAT yakni pejabat umum yang diangkat oleh Kepala Badan Pertanahan Nasional yang mempunyai kewenangan membuat akta jual beli yang bertugas untuk wilayah kerja tertentu.

c. PPAT khusus, yaitu Pejabat Kantor Pertanahan setingkat Eselon III yang diangkat menjadi PPAT dalam hal di suatu wilayah kabupaten/kota tidak tersedia PPAT.

Adapun prosedur peralihan/perolehan hak atas tanah berdasarkan jual beli berdasarkan PMNA/Ka.BPN Nomor 3 Tahun 1997, secara ringkas dapat diuraikan sebagai berikut:

a. Akta Jual Beli (AJB) bilamana sudah tercapai kesepakatan mengenai harga tanah termasuk di dalamnya cara pembayaran dan siapa yang menanggung biaya pembuatan Akta Jual Beli (AJB) antara pihak penjual dan pembeli, maka para pihak harus datang kekantor PPAT untuk membuat akta jual beli tanah.

b. Persyaratan Akta Jual Beli (AJB) hal-hal yang diperlukan dalam membuat akta jual beli tanah di kantor PPAT adalah: 
1) Syarat-syarat yang harus dibawa penjual:

a) Sertifikat asli hak atas tanah yang akan dijual;

b) Kartu tanda penduduk;

c) Bukti pembayaran Pajak Bumi dan Bangunan (PBB) sepuluh tahun terakhir; dan

d) Surat persetujuan suami isteri, serta kartu keluarga bagi yang telah berkeluarga.

2) Syarat-syarat yang harus dibawa oleh calon pembeli:

a) Kartu tanda penduduk; dan

b) Kartu keluarga.

c. Proses pembuatan AJB di kantor PPAT

1) Persiapan pembuatan AJB sebelum dilakukan proses jual beli:

a) Dilakukan pemeriksaan mengenai keaslian dari sertifikat termaksud di kantor pertanahan untuk mengetahui status sertifikat saat ini seperti keasliannya, apakah sedang dijaminkan kepada pihak lain atau sedang dalam sengketa kepemilikan, dan terhadap keterangan sengketa atau tidak, maka harus disertai surat pernyataan tidak sengketa atas tanah tersebut;

b) Terkait status tanah dalam keadaan sengketa, maka PPAT akan menolak pembuatan AJB atas tanah tersebut; dan

c) Calon pembeli dapat membuat pernyataan bahwa dengan membeli tanah tersebut maka tidak lantas menjadi pemegang hak atas tanah yang melebihi ketentuan batas luas maksimum.

2) Pembuatan Akta Jual Beli

a) Dalam pembuatan akta harus dihadiri oleh penjual dan calon pembeli atau orang yang diberi kuasa dengan surat kuasa tertulis;

b) Dalam pembuatan akta harus dihadiri oleh sekurang-kurangnya dua orang saksi;

c) PPAT akan membacakan, serta menjelaskan mengenai isi dan maksud pembuatan akta, dan bila isi akta disetujui maka oleh penjual dan calon 
pembeli akta tersebut akan ditandatangani oleh para pihak, sekaligus saksi dan pejabat pembuat akta tanah sendiri; dan

d) Akta dibuat dua lembar asli, satu disimpan oleh kantor PPAT dan lembar lainnya akan disampaikan kepada kantor pertanahan setempat untuk keperluan balik nama atas tanah, sedangkan salinannya akan diberikan kepada masing-masing pihak.

3) Setelah pembuatan akta jual beli

a) Setelah akta jual beli selesai dibuat, PPAT menyerahkan berkas tersebut ke kantor pertanahan untuk balik nama sertifikat; dan

b) Penyerahan akta harus dilakukan selambat-lambatnya 7 (tujuh) hari kerja sejak ditandatangani, dengan berkas-berkas yang harus diserahkan antara lain: surat permohonan balik nama yang telah ditandatangani pembeli, akta jual belil dari PPAT, sertifikat hak atas tanah, kartu tanda penduduk kedua belah pihak, bukti lunas pembayaran Pph, serta bukti lunas pembayaran bea perolehan hak atas tanah dan bangunan.

4) Proses di Kantor Pertanahan

a) Saat berkas diserahkan kepada kantor pertanahan, maka kantor pertanahan akan memberikan tanda bukti penerimaan permohonan balik nama kepada Pejabat Pembuat Akta Tanah yang selanjutnya akan diberikan kepada pembeli;

b) Nama penjual dalam buku tanah dan sertifikat akan dicoret dengan tinta hitam dan diberi paraf oleh kepala kantor pertanahan atau pejabat yang ditunjuk;

c) Nama pembeli selaku pemegang hak atas tanah yang baru akan ditulis pada halaman dan kolom yang terdapat pada buku tanah dan sertifikat dengan dibubuhi tanggal pencatatan, serta tandatangan kepala kantor pertanahan atau pejabat yang ditunjuk; dan

d) Dalam waktu 14 (empat belas) hari pembeli berhak mengambil sertifikat yang sudah dibalik nama pembeli di kantor pertanahan setempat. 


\section{Khilaf sebagai unsur penyebab batalnya perjanjian jual beli hak atas tanah}

Perjanjian merupakan sumber terpenting yang melahirkan perikatan, selain sumber-sumber lain yang melahirkan perikatan, yaitu undang-undang. Jadi perikatan itu lahir karena dua hal, yaitu perikatan yang lahir karena perjanjian dan perikatan yang lahir karena undang-undang. Kebatalan perjanjian jual beli hak atas tanah dapat terjadi bilamana tidak terpenuhinya syarat sahnya suatu perjanjian sebagaimana tertulis dalam Pasal 1320 KUH Perdata, yaitu: (a) sepakat mereka mengikat dirinya; (b) kecakapan untuk membuat suatu perjanjian; (c) suatu hal tertentu; dan (4) suatu sebab yang halal.

Unsur subjektifitas dalam sebuah perjanjian jual beli sangat berpengaruh pada substansi materi perjanjian tersebut. Salah satu contohnya adalah unsur khilaf. Kekhilafan (kesesatan) dibedakan dalam kekhilafan mengenai orangnya dinamakan error in persona, dan kesesatan mengenai hakikat barangnya dinamakan error in substantia terkait dengan sifat benda, yang merupakan alasan yang sesungguhnya bagi kedua belah pihak untuk mengadakan perjanjian.

Kekhilafan atau kekeliruan terjadi apabila salah satu pihak khilaf tentang hal-hal pokok dari apa yang diperjanjikan atau tentang sifat-sifat yang penting dari barang yang menjadi objek perjanjian, ataupun mengenai orang dengan siapa diadakan perjanjian itu. Kekhilafan tersebut harus sedemikian rupa hingga seandainya orang itu tidak khilaf mengenai hal-hal tersebut, ia akan memberikan persetujuan. Kekhilafan juga merupakan alasan bagi orang yang khilaf itu untuk minta pembatalan perjanjian. Adapun kekhilafan itu harus diketahui oleh lawan, atau paling sedikit harus sedemikian rupa sehingga pihak lawan mengetahui bahwa ia berhadapan dengan seorang yang berada dalam kekhilafan. Kalau pihak lawan itu tidak tahu ataupun tidak dapat mengetahui bahwa ia berhadapan dengan orang yang khilaf, maka adalah tidak adil untuk membatalkan perjanjiannya.

Suatu perjanjian merupakan suatu peristiwa di mana seorang berjanji kepada seorang lain atau dimana dua orang saling berjanji untuk melaksanakan sesuatu. Menurut R. Subekti (2002: 36), perjanjian-perjanjian (atau menurut para 
pakar lain disebut juga sebagai prestasi dalam perjanjian) dibagi dalam 3 (tiga) macam, yaitu:

a. Perjanjian untuk memberikan/menyerahkan suatu barang. Misalnya jual beli, tukar menukar, penghibahan (pemberian), sewa-menyewa, dan pinjam pakai.

b. Perjanjian untuk berbuat sesuatu. Misalnya perjanjian untuk membuat suatu lukisan, perjanjian perburuhan, perjanjian untuk membuat sebuah garasi, dan lain sebagainya.

c. Perjanjian untuk tidak berbuat sesuatu. Misalnya perjanjian untuk tidak mendirikan tembok, perjanjian untuk tidak mendirikan suatu perusahaan yang sejenis dengan kepunyaan seorang lain, dan lain sebagainya.

Melaksanakan suatu perjanjian, terlebih dahulu harus ditetapkan secara tegas dan cermat apa saja isi perjanjian tersebut atau dengan kata lain apa saja hak dan kewajiban masing-masing pihak. Biasanya orang mengadakan perjanjian dengan tidak mengatur atau menetapkan secara teliti hak dan kewajiban mereka. Mereka hanya menetapkan hal-hal yang pokok dan penting saja, dalam jual beli misalnya hanya ditetapkan tentang barang mana yang dibeli, jenis barangnya, jumlahnya dan juga harganya.

Dalam Pasal 1339 KUHP Perdata dijelaskan bahwa suatu perjanjian tidak hanya mengikat untuk hal-hal yang dengan tegas dinyatakan dalam perjanjian, tetapi juga untuk segala sesuatu yang menurut sifat perjanjiannya diharuskan (diwajibkan) oleh kepatutan, kebiasan dan undang-undang. Dengan demikian, setiap perjanjian dilengkapi dengan aturan-aturan yang terdapat dalam undangundang, dalam adat kebiasaan (di suatu tempat dan di suatu kalangan tertentu), sedangkan kewajiban-kewajiban yang diharuskan oleh kepatutan (norma-norma kepatutan) harus juga diindahkan (R. Subekti, 2002: 39).

Berdasarkan Pasal 1339 KUH Perdata tersebut, maka adat kebiasaan telah ditunjuk sebagai sumber norma selain undang-undang ikut menentukan hak-hak dan kewajiban-kewajiban kedua belah pihak dalam suatu perjanjian. Persoalan di sini apabila terdapat suatu adat kebiasaan yang berlainan atau menyimpang dari undang-undang, apakah peraturan undang-undang itu masih berlaku ataukah ia sudah disingkirkan oleh adat kebiasaan tersebut? Jawabnya ialah bahwa suatu 
pasal (peraturan) undang-undang, meskipun sudah ada suatu adat kebiasaan yang menyimpang, masih tetap berlaku dan barangsiapa pada suatu hari menunjuk pada peraturan undang-undang tersebut, harus dibenarkan dan tidak boleh dipersalahkan. Sesuatu hal tidak diatur dalam undang-undang dan belum juga ada dalam kebiasaan, karena kemungkinan belum atau tidak begitu banyak dihadapi dalam praktik, maka harus diciptakan suatu penyelesaian dengan berpedoman pada kepatutan, maka dapat dikatakan bahwa ada tiga sumber norma yang ikut mengisi suatu perjanjian, yaitu undang-undang, kebiasaan dan kepatutan.

Mengenai pembatalan perjanjian atau juga dinamakan pemecahan perjanjian sebagai sanksi atas kelalaian seorang debitur mungkin ada orang yang tidak dapat melihat sifat pembatalannya atau pemecahan tersebut sebagai suatu hukuman. Pembatalan perjanjian bertujuan membawa kedua belah pihak kembali pada keadaan sebelum perjanjian diadakan. Apabila satu pihak sudah menerima sesuatu dari pihak yang lain, baik uang maupun barang, maka hal tersebut harus dikembalikan, dan perjanjian itu batal.

Dalam hal dibatalkan, maka kedua belah pihak dibawa dalam keadaan sebelum perjanjian diadakan. Pembatalan ini berlaku surut sampai pada detik dilahirkannya perjanjian. Apa yang sudah terlanjur diterima oleh satu pihak harus dikembalikan pada pihak yang lainnya. Hal ini sesuai Pasal 1267 KUH Perdata yag menentukan bahwa pihak yang merasa perjanjian tidak dipenuhi boleh memilih apakah ia akan memaksa pihak yang lainnya untuk memenuhi perjanjian, atau ia akan menuntut pembatalan perjanjian itu disertai penggantian biaya, rugi dan bunga.

Akibat hukum perjanjian jual beli hak milik atas tanah yang mengandung atas unsur kekhilafan, maka perjanjian tersebut batal, dan terdapat penjelasan dalam Pasal 1321 dan Pasal 1449 KUH Perdata, bahwa tiada kesepakatan yang sah apabila sepakat itu diberikan karena kehilafan, atau diperolehnya dengan paksaan atau penipuan, sedangkan perikatan yang dibuat dengan paksaan, kekhilafan atau penipuan, menerbitkan suatu tuntutan untuk membatalkannya.

Syarat objektif tidak terpenuhi (hal tertentu atau kausa yang halal), maka perjanjiannya adalah batal demi hukum (null and void), sedangkan apabila syarat 
subjektif terpenuhi (tidak cakap atau memberikan perizinannya secara tidak bebas), maka perjanjian dapat dimintakan pembatalan (cancelling). Jadi ada perbedaan antara perjanjian yang batal demi hukum dan perjanjian yang dapat dimintakan pembatalan. Oleh sebab itu, sebelum membuat perjanjian/perikatan sebaiknya tahu dulu syarat sahnya suatu perjanjian.

Perjanjian yang tidak mengandung sesuatu hal yang tertentu, perjanjian yang demikian tidak dapat dilaksanakan karena tidak tentang apa yang dijanjikan oleh masing-masing pihak. Hal yang demikian dapat segera diketahui oleh hakim. Tentang perjanjian yang isinya tidak halal, perjanjian yang demikian itu tidak boleh dilaksanakan karena melanggar hukum atau kesusilaan. Hal yang demikian juga dapat segera diketahui hakim sehingga dari sudut keamanan dan ketertiban, perjanjian seperti itu harus dicegah. Tentang perjanjian yang kekurangan syaratsyarat subjektifnya yang menyangkut kepentingan seseorang, yang mungkin tidak mengingini perlindungan hukum terhadap dirinya, misalnya seorang yang oleh undang-undang dipandang sebagai tidak cakap, mungkin sekali sanggup memikul tanggung jawab sepenuhnya terhadap perjanjian yang telah dibuatnya.

Seseorang yang telah memberikan persetujuannya karena khilaf atau tertipu, mungkin sekali segan atau malu meminta perlindungan hukum. Adanya kekurangan mengenai syarat subjektif itu tidak begitu saja dapat diketahui oleh hakim, jadi harus diajukan oleh pihak yang berkepentingan, dan apabila diajukan kepada hakim, mungkin sekali disangkal oleh pihak lawan, sehingga memerlukan pembuktian, sehingga dalam hal adanya kekurangan mengenai syarat-syarat subjektif, undang-undang menyerahkan kepada pihak yang berkepentingan, apakah ia menghendaki pembatalan perjanjian atau tidak, dan perjanjian yang demikian bukan batal demi hukum, tetapi dapat dimintakan pembatalan.

Perjanjian harus disertai dengan itikad baik atau goodfaith, sebagaimana ditegaskan pada Pasal 1338 ayat (3) KUH Perdata. Apabila salah satu pihak mempunyai niat buruk (pihak yang bersangkutan telah sejak awal ada niat buruk untuk melakukan penipuan) terhadap pihak lainnya, sehingga tidak memenuhi syarat sahnya perjanjian. Artinya, perjanjian yang mengandung unsur penipuan yang dilakukan dan diniatkan oleh salah satu pihak, atau mungkin juga oleh kedua 
belah pihak dalam konteks yang sebaliknya, tentu tidak memenuhi syarat sahnya perjanjian.

Persetujuan kedua belah pihak yang merupakan kesepakatan itu, harus diberikan secara bebas, dan dalam hukum perjanjian, ada 3 (tiga) sebab yang membuat perizinan tidak bebas, yaitu:

a. Paksaan

Paksaan adalah paksaan rohani atau paksaan jiwa (phsycis), jadi bukan paksaan badan (fisik). Misalnya salah satu pihak, karena diancam atau ditakuttakuti terpaksa menyetujui suatu perjanjian.

b. Kekhilafan

Kekhilafan atau kekeliruan terjadi, apabila salah satu pihak khilaf tentang halhal yang pokok dari apa yang diperjanjikan atau tentang sifat-sifat yang penting dari barang yang menjadi objek perjanjian, ataupun mengenai orang dengan siapa diadakan perjanjian itu. Kekhilafan tersebut harus sedemikian rupa, hingga seandainya orang itu tidak khilaf mengenai hal-hal tersebut, ia tidak akan memberikan persetujuannya. Contoh kekhilafan mengenai barang, misalnya seseorang membeli sebuah lukisan yang dikiranya lukisan Basuki Abdullah, tetapi kemudian ternyata hanya turunan saja. Kekhilafan itu harus diketahui oleh lawan, atau paling sedikit harus sedemikian rupa sehingga pihak lawan mengetahui bahwa ia berhadapan dengan seorang yang berada dalam kekhilafan.

c. Penipuan

Penipuan terjadi apabila satu pihak dengan sengaja memberikan keteranganketerangan yang palsu atau tidak benar disertai dengan tipu muslihat untuk membujuk pihak lawannya memberikan perizinannya. Pihak yang menipu itu bertindak secara aktif untuk menjerumuskan pihak lawannya. Menurut yurisprudensi, tidak cukup kalau orang itu hanya melakukan kebohongan mengenai suatu hal saja, paling sedikit harus ada suatu rangkaian kebohongan atau suatu perbuatan yang dinamakan tipu muslihat.

Hak meminta pembatalan hanya ada pada satu pihak saja, yaitu pihak yang oleh undang-undang diberi perlindungan itu (pihak yang tidak cakap dan pihak 
yang tidak bebas dalam memberikan sepakat). Meminta pembatalan itu oleh Pasal 1454 KUH Perdata dibatasi sampai suatu batas waktu tertentu, yaitu 5 tahun, yang mulai berlaku (dalam hal ketidakcakapan suatu pihak) sejak orang ini menjadi cakap menurut hukum. Dalam hal paksaan, sejak hari paksaan itu telah berhenti. Dalam hal kekhilafan atau penipuan, sejak hari diketahuinya kekhilafan atau penipuan itu.

Terkait dengan cara permintaan pembatalan isi perjanjian, maka dalam praktik terdapat 2 (dua) cara yang lazim dilakukan, yaitu:

a. Pihak yang berkepentingan secara aktif sebagai penggugat meminta kepada hakim upaya perjanjian itu dibatalkan.

b. Menunggu sampai ia digugat di depan hakim untuk memenuhi perjanjian tersebut, kemudian mengemukakan bahwa perjanjian tersebut telah disetujuinya ketika ia masih belum cakap, atau karena diancam, ditipu atau khilaf mengenai objek perjanjian. Di depan sidang pengadilan itu ia memohon kepada hakim supaya perjanjian dibatalkan. Meminta pembatalan secara pembelaan inilah yang tidak dibatasi waktunya.

Batal demi hukum selain karena tidak terpenuhinya unsur obyektif, juga undang-undang merumuskan secara konkrit tiap-tiap perbuatan hukum (terutama perjanjian formil) yang mensyaratkan dibentuknya perjanjian dalam bentuk yang ditentukan oleh undang-undang, yang jika tidak dipenuhi perjanjian tersebut adalah batal demi hukum atau tidak memiliki kekuatan dalam pelaksanaannya.

Akibat hukum adalah akibat suatu tindakan yang dilakukan untuk memperoleh suatu akibat yang dikehendaki oleh pelaku dan yang diatur oleh hukum. Tindakan yang di lakukannya merupakan tindakan hukum yakni tindakan yang dilakukan guna memperoleh sesautu akibat yang dikehendaki hukum. Lebih jelas lagi bahwa akibat hukum adalah segala akibat yang terjadi dari segala perbuatan hukum yang dilakukan oleh subyek hukum terhadap obyek hukum atau akibat-akibat lain yang disebabkan karena kejadian-kejadian tertentu oleh hukum yang bersangkutan telah ditentukan atau dianggap sebagai akibat hukum.

Akibat hukum merupakan sumber lahirnya hak dan kewajiban bagi subyek-subyek hukum yang bersangkutan. Misalnya, mengadakan perjanjian jual 
beli maka telah lahir suatu akibat hukum dari perjanjian jual beli tersebut yakni ada subyek hukum yang mempunyai hak untuk mendapat barang dan mempunyai kewajiban untuk membayar barang tersebut, dan begitu sebaliknya subyek hukum yang lain mempunyai hak untuk mendapatkan uang, tetapi selain itu dia mempunyai kewajiban untuk menyerahkan barang. Jelaslah bahwa perbuatan yang dilakukan subyek hukum terhadap obyek hukum menimbulkan akibat hukum.

Terkait dengan perjanjian jual beli hak atas tanah yang di dalamnya ada syarat sah perjanjian yang tidak terpenuhi, maka konsekuensinya yang berlaku adalah:

a. Batal demi hukum, apabila tidak terpenuhinya syarat obyektif, berupa:

1) Perihal tertentu; dan

2) Kausa yang halal.

b. Dapat dibatalkan, apabila tidak terpenuhinya syarat subyektif, berupa:

1) Asas konsensualisme

2) Cakap melakukan perbuatan hukum

c. Kontrak tidak dapat dilaksanakan

Kontrak yang tidak begitu saja benar, sehingga tidak dapat dilaksanakan, misalnya, yang seharusnya dibuat secara tertulis, tetapi dibuat secara lisan.

d. Sanksi administratif

Persyaratan tidak terpenuhi, maka hanya mengakibatkan sanksi administratif saja terhadap salah satu pihak atau kedua pihak dalam kontrak, misalnya suatu kontrak memerlukan izin atau pelaporan terhadap instansi tertentu.

Khusus terhadap perjanjian jual beli hak atas tanah yang dibuat karena khilaf, berarti tidak memenuhi syarat subyektif, atau lebih tepat disebut tidak memenuhi asas konsensualisme, maka akibat hukum yang timbul terhadap perjanjian tersebut adalah dapat dibatalkan.

\section{Simpulan dan Saran}

\section{Simpulan}

Akibat hukum perjanjian jual beli hak atas tanah yang dibuat mengandung unsur khilaf tercermin dari Pasal 1321 dan Pasal 1449 KUH Perdata. Pasal 
1321 KUH Perdata telah menentukan bahwa tiada kesepakatan yang sah apabila kesepakatan itu diberikan karena kekhilafan, atau diperolehnya dengan paksaan atau penipuan, dan Pasal 1449 KUH Perdata, menentuka bahwa perikatan yang dibuat dengan paksaan, kekhilafan atau penipuan, menerbitkan suatu tuntutan untuk membatalkannya.

\section{Saran}

Diharapkan kepada seluruh masyarakat agar lebih hati-hati dan lebih cermat lagi dalam membuat suatu perjanjian agar tidak merasa dirugikan oleh bujuk rayu dan iming-iming oleh pihak yang tidak bertanggung jawab, sehingga harus diperhatikan bahwa dalam membuat perjanjian untuk memenuhi syarat sahnya perjanjian yang tertera dalam Pasal 1320 KUH Perdata. 


\section{DAFTAR PUSTAKA}

\section{Buku:}

Ahmadi Miru. 2014. Hukum Kontrak dan Perancangan Kontrak. Jakarta: PT. RajaGrafindo Persada.

Angger Sigit Prakmuti dan Erdha Widayanto. 2015. Awas Jangan Beli Tanah Sengketa. Jogjakarta: Pustaka Yustisia.

Dyah Ochtorina Susanti dan A'an Efendi. 2014. Penelitian Hukum (Legal Research). Jakarta: Sinar Grafika.

Mohammad Machfudh Zarqoni. 2015. Hak Atas Tanah. Jakarta: PT. Prestasi Pustakaraya.

Perangin-angin, Effendi. 1986. Hukum Agraria Indonesia. Jakarta: PT. RajaGrafindo Persada.

Rai Widjaya, I.G. 2007. Merancang Suatu Kontrak (Contract Drafting). Jakarta: Kesaint Blanc.

Salim H.S. 2003. Hukum Kontrak (Teori dan Teknik Penyusunan Kontrak). Jakarta: Sinar Grafika.

Subekti, R. 2002. Hukum Perjanjian. Jakarta: PT. Intermasa.

Subekti, R. dan R. Tjitrosudibio. 2009. Kitab Undang-undang Hukum Perdata (Burgerlijk Wetboek). Jakarta: Balai Pustaka.

Wawan Muhwan Hariri. 2011. Hukum Perikatan (Dilengkapi Hukum Perikatan Dalam Islam). Bandung: CV. Pustaka Setia.

\section{Peraturan Perundang-undangan:}

Republik Indonesia, Peraturan Pemerintah Nomor 24 Tahun 1997 tentang Pendaftaran Tanah.

Republik Indonesia, Peraturan Pemerintah Nomor 37 Tahun 1998 tentang Peraturan Jabatan Pejabat Pembuat Akta Tanah.

Republik Indonesia, Peraturan Menteri Agararia/Kepala Badan Pertanahan Nasional Nomor 3 Tahun 1997 tentang Petunjuk Pelaksanaan Peraturan Pemerintah Republik Indonesia Nomor 24 Tahun 1997 tentang Pendaftaran Tanah. 


\section{Jurnal/Artikel:}

Rahmat Ramadhani. 2012. "Benang Merah Alas Hak dengan Sengketa Pertanahan". Artikel. Bengkulu: Harian Rakyat-Kamis 26 Juli.

Tengku Erwinsyahbana. 2017. "Pertanggungjawaban Yuridis Direksi terhadap Risiko Kerugian Keuangan Daerah pada Badan Usaha Milik Daerah”. De Lega Lata Jurnal Ilmu Hukum. Vol. 2. No. 1. Januari-Juni. Medan: Fakultas Hukum Universitas Muhammadiyah Sumatera Utara. 


\section{BIODATA PENULIS}

$\begin{array}{ll}\text { Nama } & \text { : Fajaruddin, S.H., M.H } \\ \text { Pekerjaan } & \text { : Dosen Fakultas Hukum Universitas Muhammadiyah Sumatera } \\ & \text { Utara } \\ \text { Jabatan } & : \text { Asisten Ahli } \\ \text { Nomor HP } & : \text { 081265872288 } \\ \text { E-mail } & : \text { fajaruddin_umsu@yahoo.co.id } \\ \text { Alamat Kantor } & : \text { Jl. Kapten Muchtar Basri No. 3, Medan }\end{array}$ 